\title{
Usos del pasado territorial en el proceso de comunalización de los Comechingones del Pueblo de La Toma, Córdoba, Argentina
}

Uses of territorial past in the process of communalization by Comechingones, Pueblo de La Toma, Cordoba, Argentina

\section{Lucas Palladino}

\section{OpenEdition}

Journals

Édition électronique

URL : http://journals.openedition.org/corpusarchivos/512

DOI : $10.4000 /$ corpusarchivos. 512

ISSN : 1853-8037

Éditeur

Diego Escolar

\section{Référence électronique}

Lucas Palladino, « Usos del pasado territorial en el proceso de comunalización de los Comechingones del Pueblo de La Toma, Córdoba, Argentina », Corpus [En línea], Vol 3, No 2 | 2013, Publicado el 18 febrero 2014, consultado el 19 abril 2019. URL : http://journals.openedition.org/corpusarchivos/512 ; DOI : 10.4000/corpusarchivos.512

Ce document a été généré automatiquement le 19 avril 2019 


\title{
Usos del pasado territorial en el proceso de comunalización de los Comechingones del Pueblo de La Toma, Córdoba, Argentina
}

Uses of territorial past in the process of communalization by Comechingones, Pueblo de La Toma, Cordoba, Argentina

\author{
Lucas Palladino
}

\section{NOTE DE L'ÉDITEUR}

Fecha de recepción del original: 11/09/2013

Fecha de aceptación para publicación: 22/11/2013

En la provincia de Córdoba se ha propagado la imagen de extinción de los principales pueblos indígenas nativos: los Comechingones. Las políticas de invisibilización acopladas con prácticas de legitimación del Estado Nación contribuyeron a la difusión de este imaginario durante el siglo XIX y XX. Sin embargo, recién en el año 2001 se visibiliza, a través del Censo Nacional de Población y Vivienda del INDEC, la presencia de descendientes o Comechingones de primera generación, a pesar de que hasta el 2009 el Estado no reconocía la presencia indígena cuando comenzó con el otorgamiento de las personerías jurídicas. Los procesos de comunalización de grupos Comechingones en zonas urbanas y rurales hicieron reaparecer estas representaciones de invisibilización en algunos sectores de la población, que todavía sostenían que Córdoba estaba "libre de indios". En la ciudad de Córdoba Capital el conflicto se hizo más visible, ya que la reorganización de la Comunidad del Pueblo de La Toma, en un espacio urbano, provocó tensiones en torno la identidad aborigen. 
2 En este trabajo nos centraremos en analizar los usos del pasado territorial en las representaciones y prácticas de los adscriptos como Comechingones y no Comechingones poniendo especial atención a la disputa sobre la autenticidad aborigen ${ }^{1}$ que emerge en el marco del proceso de comunalización. Por un lado, nos interesa entender el modo a través del cual los Comechingones del Pueblo de La Toma se narrativizan (Briones, 2005) elaborando versiones de su pasado que legitiman sus prácticas comunitarias e identitarias. Por el otro, analizamos las maneras en que los otros no Comechingones que aparecieron en la disputa conciben esta reivindicación comunal. En este sentido, nos interesa también entender la manera en que las representaciones sobre el territorio aparecen en dichas narrativas en el marco de las disputas de autenticidad en el proceso de comunalización.

3 Este trabajo se basa en una investigación de carácter etnográfico llevada adelante entre los años 2008 y 2010, iniciada en el proceso de rearticulación comunal y finalizada momentos posteriores al otorgamiento de la personería jurídica. Durante el transcurso del trabajo de campo realizamos entrevistas en profundidad y observaciones participantes con quienes participaron en el proceso de comunalización. Complementamos los resultados del trabajo de campo con el análisis de textos (folletos de promoción, revistas locales, libros de historia) escritos por adscriptos Comechingones y no Comechingones durante esos años. Articulamos el trabajo con información bibliográfica y documental.

4 El artículo está organizado de la siguiente manera. En primer lugar, se elabora una caracterización de la reemergencia Comechingón en la Provincia de Córdoba atendiendo al contexto local de invisibilización oficial de la presencia de Comechingones; en segundo lugar, se discuten las perspectivas analíticas del trabajo que vinculan la discusión de los procesos de comunalización y usos del pasado territorial; en tercer lugar, se analizan las representaciones y usos del pasado territorial desde el punto de vista de las relaciones entre las prácticas Comechingonas y no Comechingonas. Desde este último apartado discutimos separadamente el papel relevante que han adquirido las fuentes documentales y de la cartografía en la legitimación de las prácticas de comunalización.

\title{
1. Reemergencia Comechingona en un contexto de extinción oficial
}

\author{
"Se fueron muriendo. Pasaron los años. La Toma \\ seguía siendo un retazo distante de terreno en el \\ mapa urbano. Los indígenas primitivos se fueron \\ muriendo. También sus descendientes." (Efraín \\ Bischoff, 1997)
}

Las representaciones de la extinción aborigen son un relato común en Argentina. Más aún en las regiones que no pertenecen a ámbitos de frontera, en donde parece asentarse el efecto civilizador de la colonización española y del Estado argentino. Los indígenas son imaginados viviendo en un pasado remoto y/o en un espacio lejano. En la Provincia de Córdoba estas representaciones fueron vehiculizadas a través las interpretaciones del pasado cordobés fusionadas entre prácticas políticas e investigaciones de científicos positivistas (historiadores, antropólogos y arqueólogos) de mediados del siglo XX. ${ }^{2}$ Estos trabajos sostuvieron que estos pueblos aborígenes habían ocupado la extensión serrana - 
occidental- de la Provincia de Córdoba hasta finales del siglo XIX y que luego, a partir de la formación del Estado argentino fueron desapareciendo por miscegenación y aculturación. Uno de estos grupos comechingones era el del Pueblo de La Toma, uno de los pocos pueblos comechingones localizados sobre la llanura oriental a la sierra, sitio donde hoy se ubica el barrio Alberdi de la Ciudad de Córdoba3. Según las narrativas oficiales la desaparición ha sido factor común en todos los pueblos aborígenes cordobeses, sin embargo el Pueblo de La Toma lo habría hecho de forma más temprana, primeramente, a partir de la creación de la Ciudad de Córdoba (1573) y, posteriormente, a partir del siglo XVIII y la urbanización en la etapa de consolidación del Estado argentino (final de siglo XIX).

6 Pero a pesar de que en la provincia de Córdoba se haya sostenido la desaparición de la población comechingona, desde finales de 1990 ha venido tomando fuerza un proceso de reemergencia indígena. Por un lado la Encuesta Complementaria de Pueblos Indígenas (ECPI) llevada a cabo durante los años 2004-2005 ${ }^{4}$ por el INDEC (Instituto Nacional de Estadística y Censo), muestra un total de 5.119 comechingones $^{5}$, por el otro, y de forma simultánea, se empiezan a organizar algunas comunidades en espacios rurales identificándose como Comechingones. Es el caso de las comunidades Tulian y Ticas del departamento de Punilla.

7 En el año 2007 en la ciudad de Córdoba un grupo de habitantes deciden hacer pública su descendencia de los Comechingones del antiguo Pueblo de La Toma. A partir de la investigación que llevó a cabo el Instituto de Culturas Aborígenes (ICA) ${ }^{6}$ en el Barrio Alberdi donde se procuró buscar a descendientes de Comechingones. En este marco se encontraron varias familias que se adscribieron como Comechingones del Pueblo de La Toma. A partir de aquí comenzaron a organizarse para formar un proyecto comunitario, buscando canales institucionales y políticos, como la solicitud de personería jurídica que otorga el INAI, para ser reconocidos como comunidad predecesora a la fundación de la Ciudad de Córdoba y a la constitución del Estado Nacional.

8 Rápidamente este proceso puso en cuestión imaginarios y concepciones sobre la identidad aborigen, pero también sobre la identidad nacional y su proceso de legitimación en la historia oficial en la Ciudad de Córdoba. A medida que iban surgiendo y reconociéndose más habitantes como Comechingones, iban apareciendo cuestionamientos, sospechas respecto a la veracidad de su identidad indígena. Es decir, comenzaron a circular representaciones sobre los aborígenes un tanto atravesadas por las políticas de blanqueamiento y europeidad de la población (Briones, 1998) asociadas a las prácticas de invisibilización y vinculadas al proceso de formación del Estado-Nación argentino.

9 Las representaciones sobre estos Comechingones por parte de los no Comechingones pusieron en cuestión la autenticidad aborigen al buscar indígenas en términos de pureza de sangre o bien a partir de rasgos culturales distintivos. En la medida que los rasgos de los Comechingones no se correspondían con los criterios "fenomíticos"7 oficiales sobre la identidad indígena, los Comechingones vivenciaron tensiones con los vecinos cordobeses, historiadores locales y políticos. Esos sectores afirmaban que la "nueva" comunidad estaba conformada en realidad por un grupo de oportunistas que aprovecharon un contexto político de valorización positiva de las minorías para obtener beneficios estatales ${ }^{8}$. 
Estas visiones sobre la comunidad comechingona se apoyaban también en el hecho que dos instituciones vinculadas con el reconocimiento y asistencia al aborigen, el Instituto Nacional de Asuntos Aborígenes (INAI) y el Equipo Nacional de la Pastoral Aborigen (ENDEPA), todavía no reconocían la existencia de Comechingones en la Provincia de Córdoba. Así, en los mapas orientados a divulgar la presencia de grupos nativos en el país no se consignaba la presencia de población comechingona en el país.

Mapas $\mathrm{N}^{\circ} 1$ y $\mathrm{N}^{\circ} 2$. Representación cartográfica que señala la localización de las poblaciones originarias en Argentina en el año 2008.

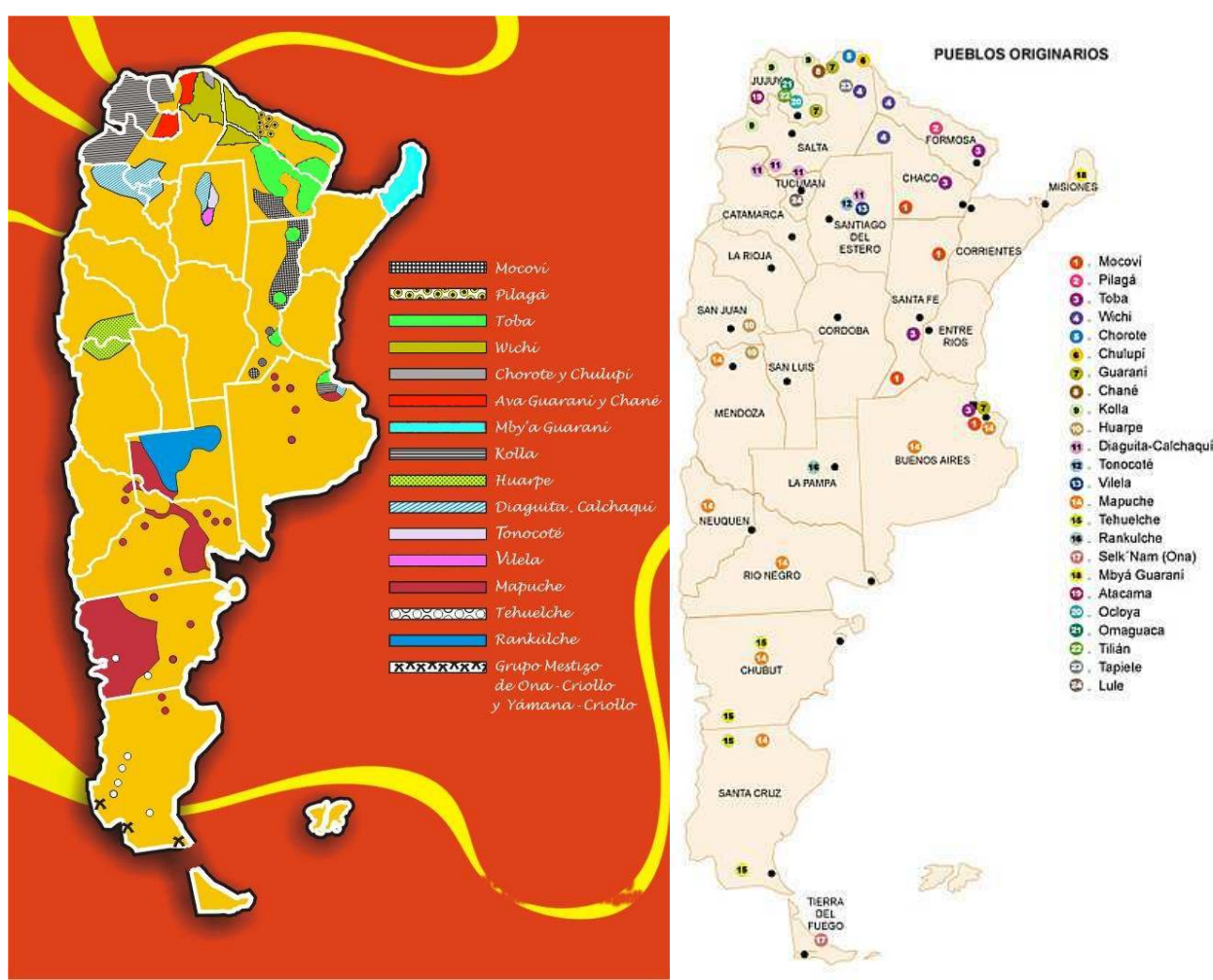

La primera imagen pertenece al Equipo de Pastoral Aborigen (ENDEPA) y la segunda al Instituto Nacional de Asuntos Indígenas (INAI). En ambas figuras no se visibilizan Comechingones en la Provincia de Córdoba

Fuente: http://www.endepa.org.ar/ y http://www.desarrollosocial.gob.ar/inai/104

En este contexto de invisibilización, los Comechingones, con la ayuda del ICA, tendrán que negociar su visibilización con la sociedad cordobesa y el Estado Nacional Argentino (a través del INAI) para ser reconocidos políticamente como comunidad. Para esto llevaron adelante una serie de prácticas a fin de posicionarse legítimamente como auténticos aborígenes Comechingones y dar validez a su proceso de comunalización. En primer lugar, decidieron reorganizarse políticamente a través de un sistema de asambleas. Esta forma de organización fue "recuperada" del sistema de cacicazgo Comechigón en donde la representación se estructuraba en torno al jefe de familia también llamado curaca. A través de este sistema se definieron siete curacas que representarían a los 325 adscriptos a la comunidad. En las asambleas se fueron definiendo tanto las estrategias políticas como las prácticas a llevar adelante para tramitar la personería jurídica frente al Instituto Nacional de Asuntos Indígenas. Seguidamente, se fue estructurando un calendario de celebraciones y eventos (en su mayoría llevados a cabo en donde se situaba el Pueblo de La Toma). Este se conformó en conjunto con otros pueblos originarios regionales y 
nacionales. Al mismo tiempo, acordaron la participación en una serie de eventos en la ciudad y provincia de Córdoba y en la ciudad de Buenos Aires. Estas prácticas tenían como meta visibilizar su propia historia y narrar el proceso de expropiación territorial del cual fueron objeto los Comechingones del Pueblo de La Toma en distintas coyunturas. Simultáneamente y con la colaboración de historiadores e investigadores del ICA ${ }^{9}$ ellos han investigado, documentado, sistematizado y luego escrito su versión de la historia. Para ello han elaborado una narrativa en la que muestran que los Comechingones ocuparon el territorio del Pueblo de La Toma antes de la llegada de los españoles y que aún durante el proceso de constitución del Estado-Nación se encontraban habitando y organizados políticamente en este territorio. Esta reelaboración de la propia versión de la historia fue justificada a través de documentos y cartografías obtenidas de archivos oficiales y religiosos. Historiadores y otros especialistas participaron en su obtención.

12 Es importante destacar que el conflicto por la definición de la autenticidad aborigen emergió de forma paralela al reconocimiento público de la comunidad Comechingón. En este sentido, la narración del pasado comunal ha tomado un carácter central en la legitimación de la identidad aborigen en este período. Por tal motivo en los siguientes apartados nos centramos en analizar los usos del cual es objeto el pasado territorial en el proceso de comunalización Comechingón.

\section{Procesos de comunalización, aboriginalidad, territorio y usos del pasado}

13 Nos interesa entender el proceso de reemergencia étnica aborigen y de formación de comunidad llevado a cabo por Comechingones del Pueblo de La Toma a través de la idea de los procesos de comunalización desarrollada por J. Brow (1990). Este término está ligado a una visión antropológica constructivista que analiza la etnicidad y los procesos de formación de grupos como producciones culturales. Para Brow estos procesos se refieren a las acciones destinadas a otorgar los sentidos de identidad compartida y de solidaridad que impulsan al devenir a los grupos en su reconstrucción como comunidad. En un sentido más estricto pensamos la comunalización en el contexto de formación de identidades aborígenes (Briones, 1998), entendidas éstas como construcciones simbólicas y materiales producidas en la relación con una alteridad situada espacial e históricamente. Entendemos que los procesos de formación de grupos aborígenes se configuran de manera discursiva y material a través de las relaciones históricas y de poder que se dan en diálogo con otros agentes. En este sentido, sostenemos la importancia de analizar la comunalización, en contextos de aboriginalidad, como procesos de constitución de identidades dinámicas, históricas y relacionales situadas en el marco de formaciones de alteridad (Briones, 2005) nacionales y provinciales ${ }^{10}$.

Brow aborda la comunalización a partir de las ideas de primordialización y de invención de la tradición. La primera supone que la comunidad tiene un origen natural, inevitable e inmemorable; la segunda es tomada de Eric Hobsbawn (1999) y se orienta a entender los mecanismos y prácticas culturales que refuerzan los procesos de primordialización. La articulación de estas dos ideas nos permite entender cómo determinados grupos tenderían a construir una narrativa propia y legítima del pasado que tuviera como motivo fortalecer los discursos de origen, demostrar la inevitabilidad de la comunidad en el pasado y su asociación con un territorio de pertenencia. 
15 Nos interesa destacar la manera en que los referentes espaciales cobran importancia distintiva en los procesos de primordialización e invención de la tradición. Tanto el pasado inmemorial como el "origen común" siempre se construyen a partir de la vinculación con el espacio de pertenencia de la comunidad. Como en el caso de los estudios de la formación de los estados, donde el territorio aparece como el ancla donde se enraízan las políticas primordialistas de la nación ${ }^{11}$. Es decir que la construcción de narrativas históricas utiliza representaciones espaciales para legitimar los relatos identitarios del presente.

Por otro lado, las prácticas de comunalización, ancladas en el territorio deben ser entendidas también en relación con los procesos de hegemonización de los estados nacionales donde están inmersos (Alonso, 1994). Estos últimos también están narrándose (Bhabha, 2000) o fabricándose (Balibar, 1991). De hecho la legitimación estatal tiene que ver con la fijación de criterios simbólicos y materiales para representarse como comunidad natural e identidad de origen que trasciende los individuos y las condiciones sociales (Balibar, 1991). El espacio, de esta manera, participaría como elemento importante en los criterios de producción de hegemonía del Estado. Para Alonso "la espacialización del tiempo, la reificación de las identidades y la organización simbólica y material del espacio social" (Alonso, 1994, p. 8) participan en el proceso de inscripción cultural (entendida como la fijación de sentido) que construye el proceso hegemónico ${ }^{12}$. Así el Estado reproduce una serie de rituales a los fines de asegurar su identidad a través de la mutua vinculación entre personas, herencia y territorio. En este sentido, construcciones discursivas en base a "metáforas botánicas" (la nación como un árbol genealógico arraigado a un suelo) o la cartografía estatal (el mapa del estado nación) actuarían como instrumentos que permiten asentar los relatos de legitimación de las naciones.

17 Esta discusión sobre la participación de lo espacial en los procesos de construcción y legitimación estatal nos sirve para entender no sólo la manera en que estos mecanismos participan y se reproducen en las representaciones identitarias oficiales -e incluso en los habitus (Bourdieu, 1977) de la población-; sino también para indagar la manera en que se producen en los procesos de comunalización de grupos aborígenes. Esto nos permite entender la manera en que el espacio aparece en el proceso de comunalización de los Comechingones al narrar su propia versión del pasado territorial frente a los actores que sostienen representaciones enraizadas en las políticas estatales de invisibilización.

18 La construcción de un pasado otorga "autoridad moral" (Brow, 1990, p. 5) y cuestiona el orden social, la doxa ${ }^{13}$ (Bourdieu, 1977) de los relatos oficiales de la historia y de quienes la construyen y legitiman ${ }^{14}$. De esta manera, a continuación veremos cómo los Comechingones elaboran un relato donde denuncian la versión del pasado promovida por el Estado nacional que desde su creación los invisibilizó y los expropió territorialmente ${ }^{15}$. La reivindicación del pasado aparece entonces, en primer lugar, para legitimar los sentimientos de pertenencia al interior de la comunidad; en segundo lugar, fortalecer los vínculos comunales en el territorio de pertenencia del Pueblo de La Toma, y en tercer lugar, lograr la visibilización legítima como aborígenes.

19 Los relatos del pasado de los adscriptos comechingones se construyen denunciando concepciones y prácticas en los que se funda y sostiene el proceso hegemónico de la nación dominante. Estas versiones del pasado cuestionan tanto las "políticas de invisibilización" (Briones, 2005; Bidaseca, 2010) como las representaciones "racializantes" y “etnizantes" (Briones, 2005) hegemónicas que, en su construcción histórica, aportaron a 
la subalternización de los grupos étnicos indígenas en Argentina. Esto está asociado a la auto-representación racial argentina en términos de blanqueamiento y europeidad (Briones, 1998, Frigerio, 2008) reflejada en ciertos discursos de algunos actores institucionales ${ }^{16}$.

Las representaciones se reflejan en los habitus de buena parte de la población no aborigen-no-comechingona, que sospecha de la existencia actual de los aborígenes usando como criterio la "autenticidad". Es decir, ella pone en duda la identidad étnicaaborigen colocando a partir de criterios como el estatuto biológico o cultural del Otro. Estos criterios sustentan los discursos invisibilizadores de las actuales reemergencias indígenas, desconocen los procesos de mestizaje e hibridación presentes en ellos y refuerzan el relato de la extinción (vivieron en el pasado en el actual territorio cordobés) y ruralización (el campo es el lugar de vida del aborigen) ${ }^{17}$.

21 En este contexto consideramos que la construcción de relatos sobre el pasado constituye una herramienta política que otorga legitimidad al renaciente proceso de comunalización de los Comechingones del Pueblo de La Toma durante los años 2008 y 2010. Estas narrativas proponen una versión del pasado que considera que ha sido estratégicamente negada por las clases gobernantes. En los siguientes apartados analizamos la manera en que los Comechingones del Pueblo de la Toma construyen y legitiman la versión propia del pasado territorial. Mostramos cómo esta versión entra en conflicto con aquella promulgada por quienes reflejan la historia oficial. Complementariamente analizaremos el papel de las fuentes documentales y la cartografía en la legitimación de tales versiones sobre el pasado territorial.

\section{Historia comechingona/ Historia oficial: relatos, usos y tensiones del pasado ancladas en el territorio}

Los relatos del pasado, que en un comienzo se enunciaron como experiencias y memorias individuales y comunales de los Comechingones fueron objetivándose a través de un proceso de reconstrucción histórica que adquiriría el carácter de historia -alternativa a la hegemónica. A medida que se reunían en asambleas, los Comechingones iban articulando las trayectorias del pasado, los conocimientos de sus antepasados y las iban enunciando tanto de manera oral y pública (presentaciones en eventos, colegios, celebraciones y conmemoraciones) como escrita (folletos, blogs de Internet, revistas y libros). A través de estas instancias se iba articulando y tejiendo lo que llamarían "su propia versión de la historia"18.

En términos generales se fueron construyendo relatos que denunciaban a los agentes y las acciones que expropiaron, desalojaron y buscaron invisibilizar a la antigua Comunidad Comechingona del Pueblo de la Toma. Estas narrativas diferenciaron tres momentos: el período de la colonización española, el de independencia y construcción del EstadoNacional argentino, y el de despojo de las tierras, vivenciado hacia mediados del siglo XX.

El momento que más ha tomado importancia en los relatos es el de la expropiación llevada a cabo en el siglo XIX, intensificado a partir del proceso de independencia. Si bien la expropiación se refleja en varias instancias, se menciona explícitamente en un folleto de promoción política de la Comunidad Comechingona del Pueblo de la Toma que elaboraron en el marco de la crítica a los festejos del bicentenario del Estado Nación Argentino de 2010: 
"En la colonia española, instituciones como el Estado, La Iglesia, el Mercado, la Justicia, y la Universidad, ejercieron un rol socializador con la clara intención de homogeneizar para hegemonizar. Construyeron desde la hegemonía un sistema que no contaba con nosotros y con nuestra cultura. (...) Luego vino el gobierno de la Emancipación nacional. Y nuestra dependencia pasó del gobierno español al gobierno criollo. Mientras muchos en la sociedad argentina se aprontan a celebrar el bicentenario, nosotros queremos recordarle al país, que mientras se desarrollaba el proceso de independencia política, los funcionarios y la burguesía local, comenzaron la compra venta ilegítima de nuestras tierras. (...) Allí están los diarios de la época [Por ejemplo El Porvenir y el Eco de Córdoba], que perpetúan en el escrito, la promulgación de leyes injustas, desalojos violentos y remates infames". (Resaltado en el original. Folleto de promoción de la Comunidad Comechingona del Pueblo de La Toma, Octubre 2008, p. 2) Pueblo de La Toma. Se centra particularmente en las prácticas del Estado (Nacional y municipal) quien fue partícipe de acciones de despojo y exterminio, omitidas en la historia narrada y celebrada en el bicentenario. Ejemplos de ello son las acciones de la venta "ilegitima" de las tierras aborígenes y el simultáneo desalojo ejecutado por funcionarios y miembros de burguesía local a finales del siglo XIX y comienzos del siglo $\mathrm{XX}^{19}$.

En otras instancias este relato ha sido articulado con la reconstrucción de las acciones de quienes se opusieron a este despojo: el Curaca Don Lino Acevedo quien, frente a la Honorable Cámara de Córdoba (1862-1890), se opone a las acciones de expropiación; los Curacas Ávalos y Cortes quienes fueron presos por oponerse al desalojo que tuvo lugar en la década de 1880 y Pedro Villafañe, quien frente al comisario Fabriciano Martínez en 1886 resistió al desalojo. Cabe destacar que este último desalojo es identificado como el momento que implicó el desaparecimiento público del Pueblo de La Toma y su denominación como Barrio Alberdi en 1910.

Desde nuestro punto de vista la narrativa comechingona establece una doble enunciación. Por un lado da cuenta del proceso de desterritorialización ${ }^{20}$ (Haesbaert, 2004) de la comunidad llevado a cabo por el Estado y por las clases dominantes por el otro, a partir de la caracterización de un modo de ocupación del espacio y de la descripción de los elementos que lo configuraban, busca instituir la certeza de la existencia de una territorialidad, aborigen y comechingona en el pasado en el Pueblo de La Toma. Así, y como se verá en el apartado sobre el análisis del uso de la Carta de Lino Acevedo, el territorio es construido discursivamente no sólo como ámbito de sobrevivencia y espacio de usufructo de los recursos naturales en el Pueblo de La Toma en el pasado, sino también como sustrato material y político del relato histórico construido por Comechingones.

La versión sobre el pasado comechingón, anclada en una antigua apropiación del espacio, entra en diálogo con los relatos de los historiadores ${ }^{21}$ que deslegitiman el proceso de reconstrucción de la Comunidad del Pueblo de La Toma. Estos historiadores afirman que quienes vivían aquí eran comunidades Sanavirones, Diaguitas o aborígenes migrantes de otros sectores del país y no Comechingones. Además, destaca que el único pueblo aborigen existente en la ciudad era Quisquisacate. Esta postura no sólo pone en tela de juicio el vínculo genético de los Comechingones actuales con los habitantes del Pueblo de La Toma en el pasado sino que también duda que los Comechingones hayan habitado en el territorio del Pueblo de La Toma. En síntesis, estos historiadores cuestionan no solo la existencia de la comunidad en el pasado sino, también la ocupación del territorio que ésta reivindica como propio. 
“En un artículo aparecido en La Voz del Interior leí que mediante un estudio se ha identificado sangre aborigen en siete familias que habitan desde hace muchos años en barrio Alberdi de nuestra ciudad. Allí se afirma que el descubrimiento acredita su ascendencia comechingona, lo que me lleva a preguntarme sobre la base de qué patrones genéticos se llega a esa conclusión. Admito que ello es posible, pero en tal caso, la radicación allí de quienes proporcionaron tal sangre se habría producido después de la creación de dicho pueblo, que en sus orígenes no fue habitado por Comechingones.

Se dice también en el artículo de marras que los Comechingones vivían allí desde antes de la llegada del gobernador Cabrera, y por boca de un sacerdote católico [Se refiere a Horacio Saravia, director del ICA] se añade que "está acreditado que fueron los Comechingones que habitaban allí los que hicieron la acequia”. En ambos casos estimo que se trata de un error. (...) No hay ninguna constancia documental de que en lo que hoy es el barrio de Alberdi hubiera un pueblo de indios a la fecha de la fundación de Córdoba. El único pueblo aborigen del que hay referencias, dentro de los actuales límites de la ciudad, es el de Quisquisacate, situado en lo que hoy es el "casco chico", el lugar elegido por Cabrera para fundar la ciudad. Así consta en la propia Acta de Fundación, labrada "en el asiento que en la lengua destos indios se llama Quisquisacate". Es posible que los habitantes de dicho pueblo fuesen de etnia comechingona, pero no puede asegurarse. Contribuye a dudar de ello el hecho de que según los filólogos que se han ocupado del tema, la voz Quisquisacate reconoce raíz sanavirona" (Resaltados en el original. Prudencio Bustos Argañaraz, http://www.adecirverdad.com/los-indios-del-pueblito-no-erancomechingones). ${ }^{22}$

Por su lado la posición de los Comechingones es explicitada en la entrevista con uno de los curacas. Este sostiene que sus antepasados comuneros residían en el área del Pueblo de la Toma desde antes de la fundación de la ciudad (año 1573). Durante el período colonial los españoles les otorgaron la propiedad de sus terrenos a través de cédulas de identificación. Esta propiedad debió ser reconocida durante el proceso de formación del Estado Nación. El siguiente testimonio destaca la presencia de los Comechingones del Pueblo de la Toma desde los tiempos prehispánicos y denuncia su invisibilización desde el relato de los historiadores de la Junta Provincial de Historia:

“(...) este guaso ${ }^{23}$ [se refiere al historiador] dice de que nosotros (está bien que tiene otra visión), nosotros no seríamos para él Comechingones porque ¡Claro! el tema acá pasa por un interés puramente económico y de intereses de elite...estos tipos, les chorearon ${ }^{24}$ las tierras en el año 86 hasta 1906, fue un despojo total que se hizo. Se pusieron dos leyes, entonces una de esas leyes arrancó en el 81 y la otra arrancó en el 86 (siglo XIX). Esas leyes generaron directamente la partición y ventas de tierras aborígenes que se transforman en tierras fiscales, de la noche a la mañana". (Alberto C., B ${ }^{\circ}$ Los plátanos, Setiembre 2008).

Así, el pasado anclado en la ocupación del territorio por parte de Comechingones se convierte en un ámbito de conflicto entre los Comechingones en su proceso de reivindicación identitaria y aquellos que reproducen argumentos que los invisibilizan. De hecho esta lectura diferencial sobre la presencia histórica y territorial de los Comechingones tiene otras consecuencias en la actualidad. Como se muestra en la entrevista anterior, los Comechingones asocian a quienes defienden la versión oficial de la historia con determinados intereses territoriales y económicos ${ }^{25}$. Tal es el caso de Prudencio Bustos Argañaraz, que desde el inicio de la aparición pública de la comunidad, comuneros indican y explicitan que él intenta invisibilizarlos. La entrevista realizada a aquel anterior Comechingón vincula directamente estos intereses territoriales con el descrédito que se le otorga a la visión de la historia de los del Pueblo de La Toma: 
“¿Cuál es el objetivo? ¿Cuál ha sido el objetivo por el cual niegan la existencia de aborígenes en Córdoba? ...Para que no reclamen tierras. Ellos han declarado que no existen aborígenes en Córdoba, automáticamente tienen las manos libres, porque dicen, como vos abrís el catastro y dice "tierras aborígenes, tierras fiscales, tierras aborígenes" Hay zonas en donde vos decís, ¿Cómo puede ser? (...) No tienen pruebas (...)". (Alberto C., B ${ }^{\circ}$ Los Plátanos, Setiembre 2008) es común en varios sectores del país, especialmente cuando se discuten los nuevos procesos de reivindicación indígena. Uno de los argumentos es que las poblaciones indígenas reconstruyen su identidad y tramitan personerías jurídicas para obtener beneficios (como la reivindicación de tierras, beneficios de programas estatales, entre otros). Esta posición parece tomar más fuerza en la ciudad de Córdoba, al ser que los Comechingones se adscriben al Pueblo de La Toma, ubicado en un espacio urbano, locus no legitimado en las representaciones de autenticidad que conciben lo rural como ámbito posible de vida de indígenas y Comechingones.

El relato de los comuneros desacredita esta perspectiva instrumentalista y señala el carácter perturbador que adquiere la rearticulación indígena para quienes se oponen a este proceso (identificados como la clase dominante) ya que la reivindicación los interpela en su carácter de cómplices de las políticas de invisibilización en el pasado. Esta posición se defiende en un texto elaborado por el ICA y una ONG local llamada Quinua arquitectura que tiene como fin "rescatar" y difundir la historia comechingona:

“(..) hay que ser conscientes que el reconocerse de la manera que lo han hecho los miembros de la comunidad, no es pasajero ni es interesado por privilegios económicos, sino que todo lo contrario, en el largo proceso que viene por delante lo que hoy vivimos va a ser más intenso y quizás molesto para algún grupo privilegiado de la sociedad". (Folleto, "Orígenes, Actualidad y Comunidad", 2009, p.

5)

En suma, el pasado construido se legitima destacando la presencia territorial de esta población y su desalojo e invisibilización a través de los procesos de conquista y construcción del Estado argentino. Dicha versión del pasado entra en tensión con aquellas interpretaciones que desacreditan la identidad comechingona. Estas últimas perspectivas hacen una lectura instrumentalista de las reivindicaciones aborígenes entendiéndola como una estrategia para obtener tierras y otros beneficios asistencialistas. Los propios adscriptos Comechingones denuncian estas posturas en tanto cómplices de la invisibilización y representativas de la versión oficial de la historia y, por lo tanto, legitimadoras de los intereses territoriales y económicos de quienes las defienden. En este marco, ellos sostienen su propia versión de historia en la cual se defiende la continuidad entre la Comunidad actual y aquella que habitó en el pasado en el Pueblo de la Toma. A partir de aquí se identifican como auténticos aborígenes Comechingones.

\section{4. "Olvidaron quemar los archivos": las fuentes documentales y los modos de legitimación de una historia alternativa}

\footnotetext{
"No hay ninguna constancia documental de que en lo que hoy es el barrio de Alberdi hubiera un pueblo de indios a la fecha de la fundación de Córdoba". (Prudencio Bustos Argañaraz, Octubre 2007).

"Curiosamente esos mismos sectores de poder, movidos por el negocio de las tierras y las aguas, olvidaron quemar los documentos (...) Esos archivos gritan nuestro
} 
ayer. Ese ayer fecundo en luchas y resistencias". (Folleto de promoción de la Comunidad Comechingona del Pueblo de La Toma, Octubre 2008).

"Ahora que estudiamos científicamente nuestro pasado, me doy cuenta que [las historias orales] son ciertas". (Comechingones en evento del Instituto Carbó, Ciudad de Córdoba, Octubre 2008).

"Hay documentos y hay mapas y hay una serie de cosas que están corroborando qué familias estaban en el Pueblo de La Toma". (Ana B., B Alberdi, Octubre de 2008).

"Ellos [Los Comechingones] saben por tradición oral lo que uno sabe por registro". (Horacio S., B ${ }^{\circ}$ Alberdi, Octubre 2008).

el Archivo Histórico Provincial y en el Archivo Histórico Municipal, en el Archivo del Arzobispado (libros de matrimonio y libros de bautismo de la Iglesia Catedral correspondientes al período comprendido entre los siglos XVII y XX) en el Registro Civil de la Provincia de Córdoba (libros de nacimiento) y en la Universidad Nacional de Córdoba ${ }^{26}$. También se rescataron documentos privados de algunos Comechingones entre los que se encontraron notas de diarios, títulos de propiedad y correspondencia de comuneros donde se narran hechos o experiencias de los habitantes del Pueblo de La Toma antes y durante la desarticulación de la comunidad. Contrariamente a lo deseado por los historiadores oficiales, los archivos poseían documentación sobre el pasado comechingón en Córdoba. Como se ve en el tercer fragmento citado en el inicio de este apartado, el uso del archivo en el proceso de comunalización ha contribuido a fortalecer la posición de que existe un pasado que no sólo se hace presente en los relatos orales de los Comechingones, sino que también se encuentra registrado en la documentación oficial. ofrecer evidencias empíricas sobre los hechos y experiencias que se narran en el relato histórico y territorial de la Comunidad ${ }^{27}$. En segundo lugar, el archivo contribuye a reconstruir y la secuencia de su desaparición (siguiendo los tres momentos que citamos: expropiación, desalojo e invisibilización) y la complicidad de los Estados (nacional, provincial y municipal) y las clases dominantes con este proceso. En tercer lugar, la documentación permite también identificar a los sectores que deseaban apropiarse de las tierras ya expropiadas durante las décadas del ' 80 y ' 90 del siglo XIX. En la actualidad ella contribuye a poner en cuestión la mirada heterónoma. De hecho, los mismos documentos que se usaron en la época colonial y republicana para invisibilizar a los Comechingones ahora son utilizados por esta comunidad para visibilizarse. Como se sostiene arriba con la frase "olvidaron quemar los documentos", para los adscriptos Comechingones esto implicó la posibilidad de que estos sean usados para su reivindicación.

Es preciso resaltar que han cobrado importancia una serie de artículos aparecidos en medios de difusión de la Ciudad de Córdoba del siglo XIX, como el diario católico "El Porvenir", "Los Principios" y el "Eco de Córdoba", en donde se hace mención a existencia de los Comechingones del Pueblo de La Toma y a las acciones de expropiación a los que fueron sometidos ${ }^{28}$. En lo que respecta a la correspondencia epistolar, se han encontrado

Corpus, Vol 3, No 2 | 2013 
cartas de antiguos Comechingones dirigidas al gobierno de la época y/o cartas de los políticos de la ciudad donde se describen sucesos sociopolíticos ocurridos en el Pueblo de La Toma a través de relevancia en el desalojo de tierras. Dentro de la correspondencia hallada en el Archivo Histórico Provincial se encuentra la carta que el ex curaca Don Lino Acevedo le escribe al gobierno municipal en el año 1882. Por su importancia en los primeros años del proceso de comunalización de los Comechingones, la analizaremos en el siguiente ítem.

\subsection{La Carta de Don Lino Acevedo y su uso en el proceso de comunalización}

La frase del historiador de la Junta Provincial de Historia citado al inicio de de este apartado: "No hay ninguna constancia documental de que en lo que hoy es el barrio de Alberdi hubiera un pueblo de indios a la fecha de la fundación de Córdoba" (Prudencio Bustos Argañaraz, Ciudad de Córdoba, Octubre de 2007) entre otras, ha tenido efectos en los relatos de los Comechingones a la hora de dar cuerpo y legitimar su versión del pasado. De hecho, ha contribuido a fortalecer la búsqueda de documentación que permitan sostener lo contrario, que "hay documentos y hay mapas y hay una serie de cosas que están corroborando que familias estaban en el Pueblo de La Toma" (Ana B., Octubre de 2008).

Consideramos que la carta del Curaca Lino Acevedo, redactada a los fines de defender las tierras de los Comechingones en el Pueblo de la Toma en el momento en que, por ley, éstas pasaban a ser mensuradas y loteadas como tierras fiscales ${ }^{29}$, se constituye en un relevante documento en el proceso de invención de la tradición y primordialización del territorio de los Comechingones. En primer lugar, ella se presenta como un documento que permite constatar la veracidad de la narrativa que sostiene la expropiación y el posterior exterminio de la Comunidad del Pueblo de La Toma en el siglo XIX. En segundo lugar, ella es usada en la actualidad, para explicar algunos aspectos de la vida de la Comunidad en el territorio del Pueblo de La Toma en el momento previo al desalojo. En tercer y último lugar, a partir de ella se da cuenta del injusto accionar que llevó a cabo el Gobierno Provincial de la época. Por ejemplo, el extracto de la carta que se presenta a continuación revela la necesidad de solicitar al Congreso Provincial la derogación de las leyes de tierras (ley 250 y 854 de 1881) ${ }^{30}$ que, si bien buscaban facilitar el crecimiento urbano de Córdoba, partirían la Comunidad Comechingona del Pueblo de La Toma y acabarían por expropiar a sus habitantes:

"Basta HC con lo expuesto para que se comprenda por lo que pueda consignarlo cuán acreedora es la comunidad del Pueblo de La Toma. Ha sido escuchada en su solicitud, y cuanta justicia se encierra en esta.

Por lo que el HC provincial pido a nombre de la comunidad que represento que tenga a bien suspender la ejecución de la ley del 27 de Dic. del 81 en cuanto ordena la división total de los terrenos del Pueblo de la Toma, sin dejar pastos comunes; pudiendo, sin perjuicio de ello, delinearse la villa y practicar los demás trabajos que se crean necesario y conveniente para la población que se ha ordenado por decreto correspondiente del PE [Poder Ejecutivo]". (Extracto de Carta del Curaca Don Lino Acevedo 1882)

La carta de Lino Acevedo es una fuente que, en diálogo con la historia oral, contribuye a construir un relato propio de la historia del Pueblo de la Toma. En dicha carta se reconoce el área bajo dominio de la Comunidad antes de la década de 1880 como también prácticas 
de subsistencia (a través de una economía basada en el pastoreo). En esta coyuntura, la Ciudad de Córdoba crece en términos de población e infraestructura siguiendo los lineamientos del estado moderno. La población del Pueblo de la Toma contribuye a este crecimiento al dotarla de tierras y de mano de obra (el escrito se refiere a la de donación de las hectáreas que realiza el Pueblo de la Toma en donde posteriormente se construyó el Cementerio San Jerónimo).

41 En la carta también se reconocen las acciones de expropiación llevadas adelante en la misma época y que culminaron con la desagregación e invisibilización de los Comechingones habitantes del área. Además, a través de ella, se interpreta el accionar de Don Lino Acevedo orientado a derogar las leyes de tierras. En el proceso de comunalización actual los comechingones asocian a Don Lino Acevedo al proceso ocurrido a partir del año 1870, en donde actuaron varios lideres en el Pueblo de La Toma, como fueron Cortes, Ávalos y Villafañe que resistieron al despojo ya formalizado por la expropiación.

Por último, la carta naturaliza la relación del territorio con la comunidad no sólo en términos de unidad de dominio político sino también de abastecimiento de recursos para su sobrevivencia ${ }^{31}$. En definitiva esta carta resultó útil a los fines de justificar la delimitación territorial que se hace hoy del Pueblo de La Toma. A través de la descripción que hace del mismo se puede corroborar tanto su localización como los usos del territorio en el pasado. En este sentido la carta, al igual que los planos catastrales de 1832 y 1890, contribuye a la localización de (los) sitios y (los) referentes espaciales a través de los cuales se construye la historia comechingona.

La relevancia de la carta en el proceso de comunalización explica que la primera celebración "propia" de los Comechingones durante su reencuentro en el año 2008 fuera la "conmemoración de la muerte de Don Lino Acevedo" (llevada adelante el 19 de agosto de 2008). En ella se rescataba al líder, y se homenajeaba su accionar en la defensa de las tierras $^{32}$.

\subsection{Des-re-territorialización, cartografía y primordialización}

Tanto en espacios públicos como en medios gráficos los Comechingones han presentado al Pueblo de La Toma como "espacio de continuidad originaria" configurando, a través del relato, un vínculo genealógico con el pasado en el territorio. Esta continuidad territorial fortalece la identidad y la comunidad en el presente. Así lo sostienen dos curacas: Lucía V y Lucía I. Lucía $\mathrm{V}$ afirma "somos comechingones porque siempre estuvimos acá" mientras que Lucía I. señala:

"[Somos] Comunidad porque sabemos que, por ejemplo, las siete familias han sido del Pueblo de La Toma, han vivido, y siguen viviendo en el Pueblo de La Toma. Pero [se refiere a quienes no viven más dentro del Pueblo de La Toma] a la vez se han ido por cuestiones que le han quitado los terrenos (...)". (Lucia I., B Villa Páez, Noviembre del 2009).

En este contexto la cartografía catastral de siglo XIX permite a los Comechingones establecer una continuidad con el pasado. En primer lugar, se busca constatar que la localidad del Pueblo de La Toma existía en el margen oeste de la Ciudad de Córdoba. En segundo, ella ayuda a identificar los terrenos pertenecientes a las familias Comechingonas en el Pueblo de La Toma antes de la expropiación y el desalojo oficial ${ }^{33}$. En tercer lugar, contribuye a delimitar el territorio legítimo que pertenecería al Pueblo de La Toma en la 
actualidad ${ }^{34}$. Por último, el catastro colabora en la constatación de la identidad indígena comechingona de los adscriptos. Es a través de esta cartografía y de la verificación de los apellidos comechingones en el Libro de Bautismo del Archivo del Arzobispado que se determina quién nació en los límites de dicho Pueblo, es decir, quién pertenece y quién no pertenece al Pueblo de La Toma. De modo general, estas operaciones identifican un "dónde estábamos" para mostrar a los Otros "quiénes somos" y de este modo justificar el "por qué estamos acá".

De hecho, durante las entrevistas, Alberto ${ }^{35}$ y Rubén recurren a los antiguos planos catastrales para justificar que el Pueblo de la Toma existía en el siglo XIX. El plano siguiente, elaborado por Ing. Ángel Machado (1890) es uno de los utilizados para justificar la presencia comechingona en el Pueblo de la Toma. Este es representado en el oeste de la Ciudad con la denominación de "La Toma" (Ver figura 2) que ya figura como uno de los primeros "barrios pueblo" de Córdoba.

Mapa $N^{\circ}$ 3: Plano de catastro Machado $1890^{36}$

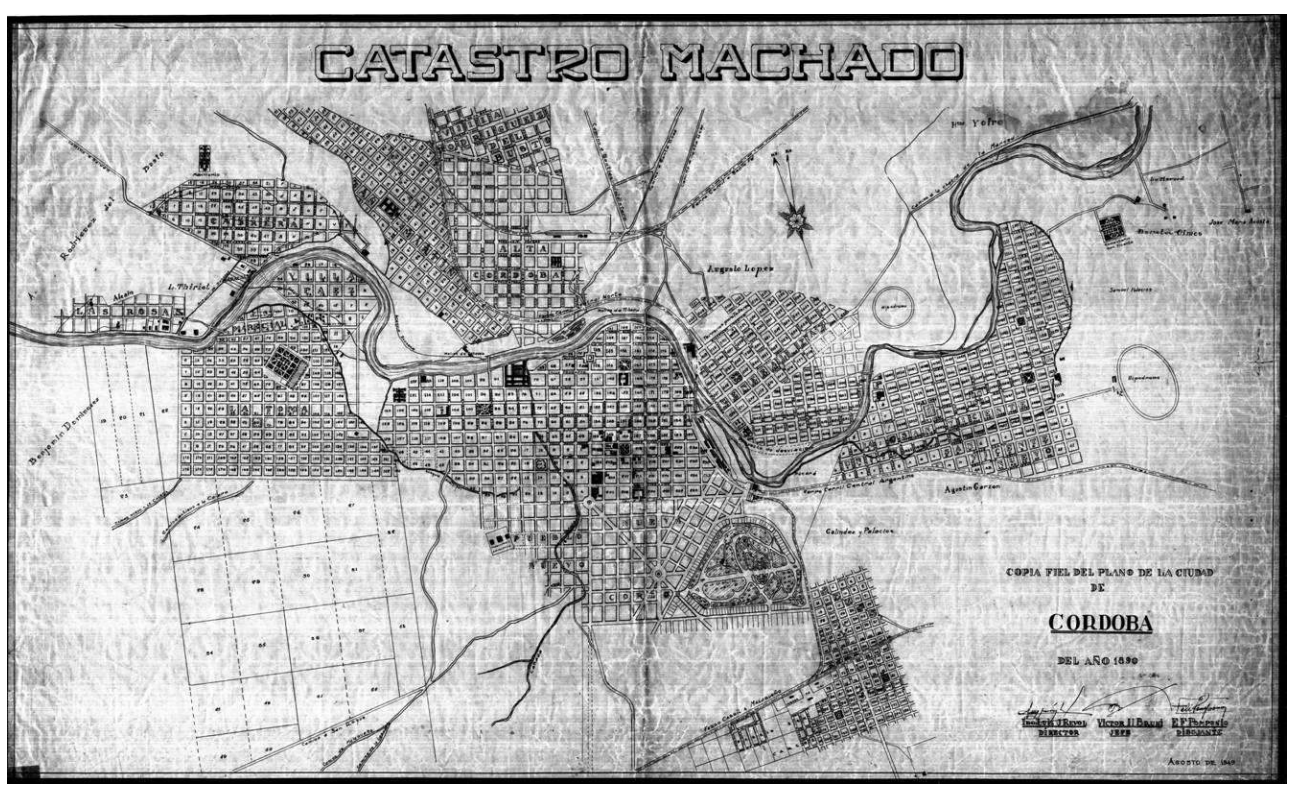

FUENTE: ARCHIVO DE COMECHINgONES DEL PUEBLO DE LA TOMA

47 El catastro Machado fue elaborado en 1890 con la intención de intervenir, planificar y controlar el espacio de la ciudad de Córdoba (Boixadós, 2006). Si bien el mapa en el siglo XIX fue un texto del poder (Harley, 2005), ahora los Comechingones, hacen un uso contrahegemónico del mismo y lo rescatan para señalar tanto las acciones de despojo del gobierno municipal como también para indicar que dicho dispositivo representa y visibiliza al Pueblo de La Toma en el siglo XIX.

Esta cartografía también ha sido usada para localizar ciertos acontecimientos ocurridos en el pasado como las luchas de los ancestros. Para ilustrar esto acudiremos a dos celebraciones. La primera corresponde a la conmemoración "El último grito de libertad" del Pueblo de La Toma (llevada a cabo el 28 de octubre de 2008). En esta circunstancia se buscaba recordar la resistencia al despojo de los comuneros del 28 de octubre de 1886 y el accionar del Curaca Pedro Villafañe que resistió a tal expropiación. En el mapa se identificó el territorio expropiado y apropiado por Fabriciano Martínez, comisario de la policía. 
49 La segunda conmemoración corresponde a la muerte de Don Lino Acevedo (llevada adelante el 19 de agosto de 2008). En este caso se recurrió al catastro para seleccionar un terreno perteneciente a la familia de un curaca ubicado en barrio Villa Páez (Pueblo de La Toma). En el discurso público los Comechingones rescataron la historia del terreno como también la lucha del curaca por los despojos ocurridos a partir de las leyes de tierras ${ }^{37}$.

En todas las circunstancias el mapa permite apoyar las denuncias al avance del sistema territorial moderno (Raffestin, 1986). Se elabora una crítica a lo que entendemos fue la producción espacial estatal (municipal) a través de prácticas de mensura, loto y venta de tierras. La configuración de un espacio geométrico, que caracteriza el entramado urbano de la ciudad y en el cual fue despojando lógicas que los actuales adscriptos como Comechingones declaran como comunales y aborígenes (no propiedad privada, uso comunal del espacio, entre otros). En contraparte, los Comechingones reconstruyen su historia en la cual no sólo manifiestan un pasado compartido y un origen espacial común (asociado al Pueblo de La Toma, indicado en el mapa), sino que consideran que las relaciones comunales que mantienen son un legado del pasado opuestas a esa espacialidad moderna.

51 En este contexto, la idea de territorio aparece también en su versión naturalista (Haesbaert, 2004) como componente indisociable de la comunidad, es decir, un constitutivo natural y necesario en la formación comunal. Además, el territorio aparece como un aspecto distintivo y fundador de todo grupo aborigen. Desde esta posición se teje una lectura romántica de la relación de la población indígena con el medio: el aborigen suele o debe vivir en comunidad, estableciendo un determinado tipo de territorialidad vinculada a la vida en conjunto y al respeto a la naturaleza en un marco rural. Es este estilo de vida el que los Comechingones del Pueblo de la Toma sostienen que han llevado adelante en el pasado ${ }^{38}$ y que la imposición del modelo europeo-moderno capitalista habría destruido. Este modelo implicó la instalación de la propiedad privada (en oposición a la propiedad comunal), el desarrollo de las individualidades (en oposición a las solidaridades colectivas), la difusión (no encuentro otra palabra mejor para no repetir otras usadas: imposición, instalación, avance) de lo moderno (en oposición a lo tradicional) y lo urbano (en oposición a lo rural) ${ }^{39}$.

52 Así los discursos de desterritorialización y reterritorialización forman parte de la comunalización. Los Comechingones consideran que la expropiación, el avance de la urbanización sobre el Pueblo de la Toma y la invisibilización de la Comunidad son procesos que dan cuenta de la desarticulación de la comunidad y la territorialización del Estado (nacional, provincial y municipal). Mientras la expropiación aparece como un modo de despojo material y físico asociado a la pérdida del territorio en el sentido de espacio físico dominado, la urbanización posterior se presenta como una estrategia de desarticulación de la vida en comunidad y la invisibilización como una estrategia política destinada a esconder los aborígenes del imaginario de la población ${ }^{40}$.

En este sentido, las relaciones comunales primordializadas, a partir de la presencia de los familiares que vivían en el territorio del Pueblo de La Toma en el pasado, construyen el Pueblo de La Toma como espacio de vida natural y constitutivo de la Comunidad, preexistente a la llegada de los agentes expropiadores. Las memorias de expropiación (Delrio, 2005) refuerzan la narrativa de la desterritorialización. Consideramos que tanto el uso de la cartografía, como de las fuentes documentales no sólo primordializan los vínculos con el territorio sino que también fortalecen el relato de la vuelta de los Comechingones al 
Pueblo de La Toma, y en este sentido, contribuyen al proceso de reterritorialización de la comunidad en la actualidad.

\section{Reflexiones finales}

54 A lo largo de este trabajo entendimos que el proceso de formación de un grupo aborigenen un contexto de extinción e invisibilización oficial- puede ser interpretado a través de la idea de procesos de comunalización. Esto nos permitió analizar dichos procesos como construcciones sociales que buscan dar sentido a los sentimientos de pertenencia y devenir de quienes se identifican como parte de una comunidad reemergente. De esta manera se hizo necesario entender las representaciones y prácticas de primordialización e invención de la tradición participes en el proceso de rearticulación comunal de Comechingones del Pueblo de La Toma.

La primordialización naturaliza los vínculos comunales asociándolos a un pasado inmemorial (anteriores a la colonización de la Corona española) y a un territorio de pertenencia pensado como sustrato básico de sobrevivencia de la comunidad. El uso de mapas y documentos de archivos, a la vez que contribuyen al proceso de primordialización, también permiten constatar el proceso de desterritorialización de los Comechingones y señalar la complicidad de los diferentes poderes (coloniales, republicanos y de clases sociales altas) en dicha dinámica. De esta manera destacamos la importancia distintiva de la activación de la tradición a partir de una historia comechingona alternativa que entrara en juego con el orden dóxico de aquella oficializada.

Tanto en el proceso de primordialización como de invención de la tradición adquirieron importancia distintiva los relatos sobre el pasado territorial. Ellos actúan como herramienta de legitimación de la reivindicación, como capital que permite a los comechingones posicionarse en tanto sujetos legítimos en la disputa sobre la identidad indígena en Córdoba. En este sentido, así como el mapa sostiene el proceso de primordialización en el territorio y contribuye a identificar los procesos modernocoloniales que desarticularon al grupo indígena, las fuentes documentales (analizados aquí a través del uso de la Carta de Don Lino Acevedo) se imponen como una herramienta que da sustancia al relato del pasado aborigen. En primer lugar, porque permite constatar la ocupación territorial y el tipo de uso del que era objeto el espacio de los Comechingones en el Pueblo de La Toma; en segundo lugar, porque contribuye a demostrar los accionares del estado municipal y provincial que, a partir de las leyes de tierras de 1882, busca expropiar y desalojar a Comechingones; en tercer lugar, porque indica que existieron ancestros que se resistieron al despojo oficial de final de siglo XIX. A partir de la identificación de ellos los Comechingones trazan continuidades genealógicas y también elaboran celebraciones y conmemoraciones en espacios que corresponden a los sucesos mencionados en el pasado en el territorio del Pueblo de La Toma. En este sentido tanto la carta como las fuentes documentales van apoyando una narrativa en donde se enuncia una cronología de las prácticas que desterritorializaron a la Comunidad Comechingón del Pueblo de La Toma en diferentes coyunturas (coloniales, republicanas). Al mismo tiempo, el reconocimiento de ancestros que resisten a esos procesos, va estableciendo esa continuidad con el pasado Comechingón. Es esa continuidad que, a nivel comunal, justifica la vuelta, reaparición y la reterritorialización de los Comechingones en la actualidad. 

también hacer legible las representaciones de los otros, no comechingones. Es decir que dicha categoría nos permite analizar procesos relacionales articulados con instancias heterónomas que también van configurando prácticas y representaciones al interior comunal. En este sentido, las prácticas comechingonas nos demostraron la aparición de otros (agentes institucionales principalmente) que, anclados en representaciones racializantes de la identidad, sostenían una mirada invisibilizadora de los Comechingones.

El conflicto que se desencadena en torno a la autenticidad aborigen, nos resulta interesante para entender los efectos de poder y la eficacia simbólica de las prácticas estatales que se enraízan en la creación Estado Nación argentino y que se han venido legitimando -en el habitus de la población- a partir de su consolidación. Consideramos que la identificación de tales prácticas, espacial y temporalmente situadas, nos permite entender las maneras en que los procesos de comunalización indígena en Córdoba disputan formaciones de alteridad (Briones, 2005) asociados a contextos de larga duración. Los procesos sociales e históricos fueron definiendo criterios, formas de validación de las identidades aborígenes tanto en términos racializantes como etnizantes y asentaron un imaginario que situaba a los aborígenes en una lejanía en términos espacio-temporales.

El concepto de procesos de comunalización y su articulación con el análisis de las representaciones sobre el pasado territorial nos otorga mayores elementos a la visualización de la discusión de la autenticidad y del papel que juega lo territorial en la reemergencia aborigen en espacios urbanos. Y nos permite tanto visibilizar los procesos de subordinación de dichos pueblos como a entender las dificultades de negociar su existencia como cuerpos políticos en el presente.

\section{BIBLIOGRAPHIE}

Alonso, A. (1994). The Politics of Space, Time and Substance: State Formation, Nacionalism, and Ethnicity. Annual Review of Anhropology. 1994. no. 23. 379-405. Trad. Sara Martínez.

Balibar, E. (1991). La forma nación: historia e ideología. En Balibar, E. y Wallerstein, I., Raza, Nación y Clase. Madrid: Iepala.

Bhabha, H. (2000). Narrando la nación. En Bravo, A. F. (comp.), La invención de la nación. Lecturas de identidad de Herder a Homi Bhabha (pp. 211-9). Buenos Aires: Manantial.

Bidaseca, K. (2010). Perturbando el texto colonial. Los estudios (pos)coloniales en América Latina. Buenos Aires: SB.

Bischoff, E. (1997). Historia de los barrios de Córdoba. Sus leyendas, instituciones y gentes. $4^{\circ}$ ed. Córdoba: Copiar.

Bourdieu, P. (1977). Outline of a theory of practice. Cambridge: Cambridge University Press.

Corpus, Vol 3, No 2 | 2013 
Boixadós, M. C. (2000). Las tramas de una ciudad, Córdoba 1870 -1895, elite urbanizadora, infraestructura doblamiento. Córdoba: Ferreyra.

Boixadós, M. C. (2006). Las representaciones cartográficas de la Ciudad de Córdoba. Entre 1870 a 1930. En Carla Lois (coord.) Imágenes y lenguajes cartográficos en las representaciones del espacio y del tiempo (pp. 17-26). Buenos Aires: Universidad de Buenos Aires.

Briones, C. (1998). La alteridad del "cuarto mundo". Una deconstrucción antropológica de la diferencia. Buenos Aires: Ediciones del Sol.

Briones, C. (2005). Cartografías argentinas. Políticas indigenístas y formaciones provinciales de alteridad. Buenos Aires: Antropofagia.

Brow, J. (1990). Notes on Community, Hegemony, and Uses of the Past. Anthropological Quarterly, no. 1, 1-6.

Ciica, (2009). Hijos del Suquía. Los Comechingones del Pueblo de la Toma, actual barrio Alberdi, ayer y hoy . Córdoba: Imprentica.

Delrio, W. (2005). Memorias de expropiación. Sometimiento e incorporación indígena en la Patagonia 1872-1943. Buenos Aires: Ed. Universidad Nacional de Quilmes.

Derrida, J. (1977). Mal de archivo. Una impresión freudiana. Madrid: Trotta.

Escolar, D. (2007). Los dones étnicos de la Nación: identidades huarpe y modos de producción de soberanía en Argentina. Buenos Aires: Prometeo.

Frigerio, A. (2008). De la "desaparición" de los negros a la "reaparición" de los afrodescendientes: Comprendiendo la política de las identidades negras, las clasificaciones raciales y de su estudio en la Argentina. En Lechini, G. (comp.), Los estudios afroamericanos y africanos en América Latina: herencia, presencia y visiones del otro (pp. 117-144). Buenos Aires: CLACSO.

Haesbaert, R. (2004). o mito da Desterritorializaçao. Do "fim dos territórios" à multiterritorialidade. Río de Janeiro: Bertrand.

Harley, J. (2005). La nueva naturaleza de los mapas. Ensayos sobre la historia de la cartografía. Ciudad de México: Fondo de Cultura Económica.

Hobsbawn, E. (1999). Inventando Tradiciones, Revista Bitarte, no. 18, 39-53.

Lázzari, A. (2007). Deseo de autenticidad, sospecha y autonomía: la revitalización de la lengua en el reconocimiento del pueblo indígena Rankülche. En Gordillo, G. y Hirsch, S. (editores). Luchas indígenas e identidades en disputa en Argentina: historias de invisibilización y emergencia (pp. 147-172). Buenos Aires: Prometeo.

Montes, A. (2008). Indígenas y conquistadores de Córdoba. Buenos Aires: Inquistipe.

Page, C. (2007). El pueblo de indios de La Toma en las inmediaciones de Córdoba del Tucumán. Un ejemplo de asentamiento periférico. Siglos XVII al XIX, Cuadernos de Historia, Serie Ec. y Soc., no. 9, 105-137.

Palladino, L. (2010). Procesos de Comunalización y Territorio. El Caso de la Comunidad Comechingona del Pueblo de La Toma (2008-2009), Córdoba. Tesis de grado. Departamento de Geografía, Facultad de Filosofía y Humanidades, Universidad Nacional de Córdoba.

Palladino, L. (2013). Procesos de comunalización y espacialidad de la memoria. El caso de la Comunidad Comechingón del Pueblo de La Toma, Córdoba. Anales de la Reunión de Antropología del Mercosur. Ciudad de Córdoba.

Raffestin, C. (1993). Por uma geografia do poder. San Pablo: Ática. 
Ramos, A. (1997). Discurso, pertenencia y devenir. El caso mapuche de Colonia Cushamen. Anales del V Congreso de Antropología social, Ciudad de La Plata.

http://www.arqueologia.com.ar/congresos/contenido/laplata/LP4/19.htm

Rojas Martínez, A. (2005). Si no fuera por los quince negros. Memoria colectiva de la gente negra de Tierradentro. Cali: El Cauca.

Serrano, A. (1945). Los Comechingones. Córdoba: Universidad Nacional de Córdoba.

Tell, S. (2010). Expansión urbana sobre tierras indígenas. El pueblo de La Toma en la Real

Audiencia de Buenos Aires, Revista Mundo Agrario, [On Line]. 20. Disponible en: http://

www.scielo.org.ar/scielo.php?pid=S1515-59942010000100009\&script=sci_arttext

Sitios Web

http://archivo.lavoz.com.ar/nota.asp?nota_id=127814

http://www.adecirverdad.com/los-indios-del-pueblito-no-eran-comechingones

http://www.marianosaravia.com.ar/la-cordoba-genocida/

http://www.endepa.org.ar/

http://www.desarrollosocial.gob.ar/inai/104

http://comechingonesdelpueblodelatoma.blogspot.com.ar/

http://www.desarrollosocial.gob.ar/Uploads/i1/Institucional/6.InformacionEstadistica.pdf

\section{Otros materiales de divulgación consultados:}

Folleto promoción de la Comunidad Comechingona del Pueblo de La Toma, Octubre 2008.pp. 1-5.

Folleto de promoción de la cerámica de la Comunidad Comechingona del Pueblo de La Toma. ORIGENES, ACTUALIDAD Y COMUNIDAD. Noviembre 2009. Cap. 1, 2 y 3. pp. 1-27.

Pachamama, revista del Instituto de Culturas Aborígenes, edición número 22, abril de 2010

Notas

\section{NOTES}

1. Existen otros trabajos que han tratado la problemática de la autenticidad aborigen, entre ellos el de Diego Escolar (2007), Claudia Briones (1998), Ana Ramos (1997) Axel Lázzari (2007) y Karina Bidaseca (2010).

2. Entre estos estudios podemos mencionar los de Montes (2008) y Serrano (1945). Estas investigaciones no ofrecen una única visión sobre la localización de Comechingones. No todas defienden la extinción de los Comechingones. En el caso de la ciudad de Córdoba, un trabajo que menciona la desaparición de esta comunidad en el Pueblo de La Toma es el de Bischoff ([1992]1997).

3. Algunos de los trabajos históricos (Montes, 2008; Bischoff, 1997; Boixadós, 2000; CIICA, 2009; Page, 2007; Tell, 2010) afirman que el Pueblo de La Toma era uno de los nueve "pueblo de indios" de la Provincia de Córdoba. Si bien difieren en afirmar en que pertenecían a Comechingones o Calchaquíes inmigrantes, coinciden en utilizar la categoría para mencionar las reducciones indígenas que se establecieron luego de la colonización y que permaneció hasta el proceso de consolidación del Estado Argentino (Vía constitución de 1853). Para Boixadós (2000) y Tell (2010) 
el Pueblo de La Toma fue uno de los pocos pueblos de indios de la provincia de Córdoba que logró tener tierras comunales hasta 1885.

4. Si bien el censo constituyó un momento oficial de reconocimiento indígena en Córdoba es preciso aclarar que antes de la elaboración del mismo ya existían reivindicaciones comechingonas en el noroeste provincial, en la localidad de San Marcos Sierras. Tal es el caso de la Comunidad Tulián que se venía organizando desde finales de los 90'.

5. Cabe destacar que el censo del 2001 contempló entre sus objetivos cuantificar y caracterizar la población aborigen en Argentina incorporando un casillero en donde se dejaba constancia de la autoidentificación indígena de la población. La Encuesta Complementaria de Pueblos Indígenas se llevó adelante a los fines de contar con información a escala provincial sobre la localización (urbana y rural) y la categoría de identificación descendientes o indígenas de aborígenes.

6. Esta es una institución local de enseñanza terciaria que ha sido formada por aborígenes migrantes en la ciudad de Córdoba en el año 1992. El ICA es reconocido por su militancia a favor de las políticas de reconocimiento de las identidades aborígenes en la ciudad. Su director es un cura e historiador llamado Horacio Saravia y que se adscribe al Pueblo Kolla del norte argentino.

7. Utilizamos el término "fenomitos" acuñado por Diego Escolar (2007) para designar la manera en que se han instalado representaciones estandarizadas sobre la identidad indígena y que han derivado en formas de validación de la autenticidad. Para el autor existen dos mitos particulares que circulan como imaginarios en la población no aborigen. En primer lugar, el criterio biológico representado a través del fenotipo (los rasgos biológicos, la "cara de indio"), en segundo lugar, el criterio culturalista, representado a través de los aspectos étnicos de la población (lengua, vestimenta, alimentación, religión, entre otros).

8. Se sostiene que la lucha por el reconocimiento identitario se orienta a obtener beneficios materiales como dinero del Estado o tierras. Por ejemplo, el FFEI (Fundación Filosófica Ecológica e Intercultural) un grupo reconocido por su fomento a las culturas originarias en Córdoba, han colocado el carácter de duda al respecto de la identidad indígena de los adscriptos como Comechingones. Este grupo justifica su posición en el hecho de considerar que los Comechingones carecen de mitos y leyendas. Ello los lleva a reconocer un "sospechoso oportunismo" dentro de las personas que se conciben como Comechingones.

9. El papel del ICA a través del Centro de Investigaciones del Instituto de Culturas Aborígenes (CIICA), conformado por historiadores y profesores de dicho instituto, fue fundamental para la rearticulación de los Comechingones. Cabe destacar también el protagonismo de Horacio Saravia (presentado en nota número 6) y Adriana Gleser -historiadora- directora del CIICA. Ellos han llevado adelante una investigación importante sobre la base de las fuentes documentales. El trabajo del CIICA devino en la producción de un valioso libro sobre la historia y presente de los Comechingones del Pueblo de La Toma. El libro se titula "Hijos del Suquía" y fue publicado por la editorial del ICA (Imprentica) en el año 2009. Muchas de las discusiones que presenta este artículo reflejan los debates registrados en el proceso de construcción de este libro.

10. Si bien nos basaremos en los discursos de Comechingones queremos subrayar que nuestra perspectiva teórica no enfatiza la dimensión de la agencia por sobre la estructura. En este sentido, consideramos que tanto las representaciones sobre la identidad como las prácticas de los Comechingones del Pueblo de La Toma no pueden reducirse solamente a su discurso. Es preciso tener en cuenta las relaciones de poder que se dan con otros agentes involucrados. Al sostener la aboriginalidad en tanto construcción relacional y contrastiva, precisamos comprender también las configuraciones de sentido y representaciones que los otros grupos "no aborígenes" otorgan en principal el Estado- ya que los mismos discursos no operan en el vacío y tienen un papel importante en la configuración de condiciones materiales de existencia (Briones, 1998; Ramos, 1997). En este sentido nos interesa entender cómo los Comechingones en su proceso de comunalización construyen representaciones sobre sí mismo y cómo al mismo tiempo construyen y contestan al "otro" que también los configura. 
11. Desde nuestra lectura, Brow usa la categoría de territorio en términos de la valoración simbólica que tiene la población hacia el entorno. En este trabajo pretendemos articular la dimensión simbólica de las representaciones del territorio, con la cuestión económica-política al estilo del geógrafo Rogério Haesbaert (2004) al proponer el concepto en términos relacionales e integrales. Esta noción entonces nos permite vincular representaciones territoriales en los planos materiales y simbólicos con los procesos de comunalización. En este sentido, podemos analizar los procesos por los cuales la comunidad va configurando una importancia decisiva en base a los espacios de referencia identitaria.

12. Notamos que para Alonso el espacio participa en la configuración del Estado tanto en un sentido material (procesos de organización del espacio) como simbólico (proceso de fijación de sentido para legitimar la identidad nacional).

13. Basándose en las ideas de Pierre Bourdieu, Brow define a la doxa como un conjunto de creencias y prácticas sociales que son consideradas normales (o verdaderas) en determinado contexto social. La doxa es estructurada por la clase dominante a los fines de definir el mundo social. Desde esta perspectiva, la doxa tiene un amplio poder simbólico; ella es la condición para que se mantenga el estado de las cosas en una sociedad (Bourdieu, 1977).

14. En este sentido también Rojas Martínez afirma que "Los pueblos reformulan su propio conocimiento histórico como arma para enfrentar su subordinación social. Para ellos la historia constituye una forma de conocimiento sobre los orígenes de esta situación, así como una fuente de información sobre sus derechos legales. Al mismo tiempo les sirve como inicio de una nueva definición de si mismos (...)" (Rojas Martínez, 2005, p. 23).

15. Nos valemos del concepto de "usos del pasado" para dar cuenta de cómo determinadas representaciones y prácticas sobre el pasado contribuyen a anclar sentidos de pertenencia y solidaridad entre los miembros de la comunidad. Destacamos también que existen diferentes usos del pasado, incluso al interior de los Comechingones.

16. Un estudio sobre afrodescendientes en Argentina nos permite entender algunas representaciones sobre la "imagen ideal" de la sociedad argentina elaborada por la narrativa dominante. Para Frigerio, dicha narrativa construye a la sociedad argentina como "blanca, europea, moderna, racional y católica" (2008, p. 7). Al tiempo que la construye en estos términos sus prácticas tienden, en primer lugar, a invisibilizar las presencias étnicas reemergentes, en segundo lugar, a situarlas en la lejanía temporal y geográfica y; en tercer lugar, a mostrarse ciega al respecto de los procesos de hibridación y mestizaje. Por otro lado es importante mencionar los estudios que muestran la tensión entre grupos aborígenes reemergentes y discursos oficiales (Briones, 2005; Escolar, 2007; Lazzari, 2007, entre otros). Un común denominador que es enfocarse en la tensión que colocan los grupos reemergentes frente a las representaciones oficiales de la identidad nacional. En este contexto también aparece la noción racializada de lo étnico que se origina en políticas del Estado argentino que invisibiliza cualquier evidencia que no se corresponda con dicho canon. Estas representaciones se encuentran presentes en los discursos que buscan identidades "auténticas" en base a criterios mencionados y niegan la posibilidad de pensar aborígenes o afrodescendientes como habitantes legítimos del país. También Bidaseca reflexiona sobre esto: "El poder se pregunta quién es verdadero indio. El ideario de una nación homogéneamente blanca y europea se construye a partir de la negación, invisibilización, borramiento de otras alteridades: indígena y afro-descendientes." (Bidaseca, 2010, p. 149).

17. Nos resulta interesante la referencia de Briones respecto de la negación indígena en Argentina: "Argentina ha sido un país tan negador que la lucha indígena más sostenida ha pasado y pasa por lograr visibilidad y por vencer estereotipos que no sólo asumen la desindianización en contextos urbanos, sino que instalan severas sospechas sobre la autenticidad de los intelectuales indígenas, cuya escolarización o capacidad política los distancia del "indígena verdadero" tan pasivo e incompetente como sumiso y fácil de satisfacer desde políticas asistenciales mínimas" ( Briones, 2005, p. 44). 
18. A partir de los resultados mostrados a lo largo del trabajo entendemos que el proceso de invención de la tradición se elabora a partir de la objetivación de experiencias como de memorias particulares y comunales y de su reconstrucción histórica a través de fuentes documentales y bibliográficas.

19. Para un recorrido sobre las acciones de las elites gobernantes y su papel en el crecimiento de la ciudad se puede consultar Boixadós (2000).

20. Destacaremos el concepto de desterritorialización para realizar la caracterización de las acciones de expropiación y despojo llevados a cabo por el Estado y las clases gobernantes frente a los Comechingones. Sostenemos como Haesbaert (2004) que no puede entenderse la desterritorialización sin un efecto siguiente que es la reterritorialización. Haesbaert (2004) sostiene en este sentido que las prácticas de desterritorialización generaron nuevos movimientos de apropiación y dominación espacial por el Estado.

21. Consideramos como historiadores oficiales aquellos que han aparecido en el relato de los Comechingones como los protagonistas de la discusión sobre la identidad aborigen. A través de exposiciones, debates y escritos en diarios locales, estos historiadores han procurado invisibilizar a los Comechingones. Entre ellos se destacan los miembros de la Junta Provincial de Historia (Emilio Rojas de Villafañe y Prudencio Bustos Argañaraz). Estos historiadores se basan en los estudios de arqueólogos y antropólogos clásicos llevados adelante en la primera mitad del siglo XX por Aníbal Montes, Antonio Serrano y Rex González para sostener que la población originaria de Córdoba forma parte únicamente del pasado. Sin embargo, hay que tener en cuenta que entre estos especialistas no hay consenso respecto a la no existencia de comunidades comechingonas en Córdoba en el siglo XX. Por ejemplo, Aníbal Montes ha sostenido la presencia de descendientes de Comechingones en dicha época. Por tal motivo sus textos son recuperados por la comunidad comechingona en sus reivindicaciones. Cabe destacar también que existen otros historiadores que se han manifestado a favor de las reivindicaciones de los Comechingones en la actualidad. Es el caso de Francisco Bauer (quien ha participado de la presentación del libro "Hijos del Suquía"), Efraín Bischoff y Alberto Assadourian. Aquí también vale destacar que algunos de ellos cambian su posición conforme al contexto. Por ejemplo, E. Bischoff, oralmente reconoció a los Comechingones. Sin embargo, en sus textos sostiene la desaparición del Pueblo de La Toma (ver Bischoff, 1997).

22. En artículos periodísticos Bustos Argañaraz intenta demostrar también que los habitantes del "Pueblito" no eran verdaderos Comechingones. Por tal motivo afirma: "Con los años la población del Pueblito se fue diversificando aún más y produciéndose numerosos cruces con gente provenientes de otros sitios, por lo que es altamente probable que ingresara de esa manera sangre comechingona" (Bustos Argañaraz, Diario La Voz Del Interior, 27-10-2007). Así, para este historiador "la pureza de sangre" es un criterio clave para definir la autenticidad aborigen. Pero el historiador también se manifiesta claramente en contra de los actuales procesos de reivindicación de comunidades originarias por su supuesta falta de autenticidad. Ello lo expresa en el siguiente fragmento "Hay una marcada tendencia a adjudicar origen comechingón a grupos que no parecen pertenecer a dicha parcialidad. En San Marcos Sierras se realiza anualmente una simpática celebración denominada Tulianadas, cuyo nombre es debido a una importante familia de la zona, de apellido Tulián, que dicen tener procedencia comechingona. Sin embargo, no conozco la existencia de elementos que lo prueben (...)" (Bustos Argañaraz, Diario La Voz Del Interior, 27-10-2007)

23. Se trata de un término popular que es utilizado irónicamente como sinónimo de persona.

24. La palabra "chorear" es utilizada en la jerga popular de argentina para hacer referencia a la acción de "robar".

25. Los Comechingones así como los miembros del ICA han asociado esta postura con sus intereses territoriales. Así, los Comechingones afirman que el historiador Prudencio Bustos Argañaraz posee terrenos en algunos de los actuales barrios que serían parte del antiguo Pueblo 
de La Toma. También indican que el ex gobernador de la Provincia de Córdoba, Eduardo Angeloz (1983-1987), quien habría sostenido que en Córdoba no existían aborígenes, es dueño de gran parte de los campos del norte de la Provincia de Córdoba. Los reclamos de los pueblos originarios sobre esas tierras pondrían en cuestión sus títulos de propiedad.

26. El Archivo Histórico Provincial contiene los documentos públicos correspondientes a la actual Provincia de Córdoba desde 1574 hasta 1925. Entre los siglos XVII y XIX el Archivo del Arzobispado fue el único registro de personas hasta la creación del Registro Civil. Luego, este último ha provisto el libro de nacimientos de la Provincia de Córdoba. La Universidad Nacional de Córdoba (creada en 1613 por jesuitas) reúne también documentos que pueden ser relevantes para la comunidad, aunque no han sido utilizados tan directamente como los correspondientes a los dos archivos citados anteriormente.

27. Seguimos a Derrida al destacar que no hay "Ningún poder político sin control del archivo, cuando no de la memoria." Y que "la democratización efectiva se mide siempre por este criterio esencial: la participación y el acceso al archivo, a su constitución y a su interpretación" (Derrida, 1977)

28. Actualmente los Comechingones disponen de varios artículos publicados en estos diarios. La mayoría de ellos tienen que ver con cuestiones tales como promulgación de las leyes de tierras, remates judiciales y desalojos. Cabe aclarar que estos medios de difusión gráfica se mostraban como opositores al gobierno municipal.

29. Nos referimos a la implementación de las leyes de tierras a nivel provincial (1860) en donde toda tierra que no era considerada privada y con menos de 30 años de ocupación debía ser fiscalizada. Esto implicó que las tierras comunales del Pueblo de La Toma fueran loteadas y mensuradas hasta el año 1885 (Tell, 2010).

30. Estas leyes parten de una política de tierras iniciadas por el gobierno nacional en 1862 que deriva en prácticas de mensura y amojonamiento de los territorios públicos para ser incorporados al Estado. Estas dos leyes ordenaban mensurar y dividir las tierras de las comunidades aborígenes. Finalmente el 27 de diciembre de 1881 se ordena la mensura y partición del territorio del Pueblo de La Toma (CIICA, 2009).

31. En otros extractos Don Lino Acevedo describe el vínculo entre la comunidad y la naturaleza a través de las prácticas agrarias. Con argumentaciones próximas al determinismo ambiental, este curaca demuestra la necesidad de la comunidad de contar con ese espacio para sobrevivir. Una lectura más detallada de los usos de esta carta por parte de la comunidad comechingona ver Palladino (2010, p. 97 -106).

32. En los actos públicos varios Comechingones destacan con orgullo ser descendientes de Don Lino Acevedo. Tal es el caso de Alberto Canelo y Argentina Acevedo. Esta última se ha presentado en varias instancias como "Argentina Acevedo tataranieta del Curaca Don Lino Acevedo".

33. Accedimos a una reproducción de la cartografía utilizada por españoles en donde figura "El Pueblo de La Toma" en el siglo XVIII que figura en el artículo de Tell (2010). Esta reproducción también fue utilizada por los Comechingones y el ICA. Estos últimos han accedido a los documentos presentes en la Oficina de Catastro buscando comparar diferentes planos del siglo XIX con la intención de evidenciar los cambios en la propiedad de las tierras y la titularidad a los fines de corroborar el avance urbano de Córdoba hacia el Pueblo de La Toma.

34. Si bien en las entrevistas los curacas sostenían que la comunidad no poseía pretensiones territoriales, esta delimitación es solicitada por el INAI para la obtención de la personería jurídica. En dicha solicitud se requiere que la comunidad demuestre la extensión de su territorio en el pasado. Por tal motivo los Comechingones han elaborado un mapa en donde definen los límites territoriales del Pueblo de La Toma antes de 1886 y ubican los domicilios actuales de los curacas dentro de esos límites. De esta manera pretendieron justificar ante el INAI que continúan viviendo dentro de los límites representados.

35. Ver el segundo extracto de entrevista a Alberto en la página número 9. 
36. Según Boixadós (2000), en el plano de 1889 firmado por Santiago Albarracín - incorporado en la publicación oficial titulada "Bosquejo Histórico, Político y Económico de la Provincia de Córdoba se incluyen los nuevos barrios con sus respectivos conjuntos de manzanas. Dentro de estos aparece el Pueblo de La Toma, designado como "el Pueblito". Del mismo modo, el plano de Machado de 1890 expresa esta división y muestra al Pueblo de La Toma solo con el nombre de "La Toma" (Ver figura 2).

37. Es importante destacar que las conmemoraciones comechingonas actúan como espacios de conmemoración y recuerdo y por lo tanto son parte del proceso de invención de la tradición (Palladino, 2013). Estas instancias también reconstruyen lazos con los ancestros que se habrían resistido a la expropiación estatal en diferentes coyunturas. Del período colonial se reconocen a aquellos que tuvieron un rol importante en la negociación con la corona española. Entre ellos se destacan José Antonio Deiqui (Curaca entre 1770 y 1799) y Juan de Dios Villafañe (Curaca en 1805). Posteriormente Lino Acevedo, Félix Cortés, Gregorio Cortés, José Álvarez, Domingo Salinas, Pedro Villafañe resistieron a la expropiación y el desalojo en el período de formación del estado nacional y provincial (1853 a 1910). La identificación con estos personajes históricos permite nutrir la narrativa histórica de la Comunidad al establecer una continuidad genealógica en el territorio. Además, presenta a estos ancestros como "héroes" y fortalece la idea del despojo estatal.

38. Aparte de la familia Villarreal, que explícitamente manifiesta el despojo en la década del 70, la familia Acevedo destaca haber iniciado un proceso judicial para la recuperación de algunas tierras.

39. Este tipo de reclamo se expresa, por ejemplo, en otro acto público cuando Horacio Saravia expresaba: "La ciudad los invadió y el Pueblito de La Toma quedó invisibilizado pero nadie los pudo exterminar". Interpretamos que la categoría "ciudad" es vista como representativa de lo moderno opuesta a lo tradicional representado en la vida en comunidad de los aborígenes. En este sentido, se expresa que a pesar de que la ciudad (modernidad, urbanización) se impuso, ellos han resistido.

40. Es preciso aclarar que los Comechingones usan el término invisibilización para referirse a la estrategia que llevó a cabo el Estado, mediante el sistema educativo (entre otros medios) a los fines de no dar a conocer su existencia en el pasado. El uso de esta noción por parte los miembros del CIICA contribuyó a su incorporación dentro de la comunidad.

\section{RÉSUMÉS}

En el año 2008 un grupo de familias se proclaman como Comechingones pertenecientes al antiguo Pueblo de La Toma e inician un proceso de rearticulación comunal en la Ciudad de Córdoba. Este proceso de comunalización provocó tensiones ya que rápidamente aparecieron versiones sobre el pasado territorial y la identidad -asociadas a representaciones oficiales históricas de invisibilización - que sospechaban de la autenticidad aborigen de quienes se adscribían como Comechingones. En este marco este trabajo analiza el papel que juegan las representaciones del pasado territorial en el contexto de la disputa por la autenticidad que ha involucrado el proceso de comunalización de los Comechingones del Pueblo de La Toma. La información se obtuvo del trabajo etnográfico llevado en el período 2008-2010 e involucró observación participante, entrevistas y análisis de fuentes documentales. 
In 2008 a group of Comechingones families proclaimed themselves as inhabitants of the old Pueblo de La Toma and initiated a process of rearticulation in the city of Cordoba. This communalization process caused tensions within the city. Versions about the territorial past and identity- related with historical official invisibilization representations- suspected of the aboriginal authenticity of those groups considered themselves as Comechingones. Within this framework this paper analyzes the role of territorial representations of the past in the context of the struggle over authenticity that has involved the communalization process of Comechingones of the Pueblo de La Toma. The information was obtained from ethnographic work conducted between 2008-2010. It involved participant observation, interviews and analysis of documentary sources.

\section{INDEX}

Keywords : communalization processes, uses of the past, territory, aboriginal authenticity, comechingones

Palabras claves : procesos de comunalización, usos del pasado, territorio, autenticidad aborigen

\section{AUTEUR}

\section{LUCAS PALLADINO}

Centro de Investigaciones de la Facultad de Filosofía y Humanidades CIFFYH - CONICET (Consejo Nacional de Investigaciones Científicas y Técnicas) - Universidad Nacional de Córdoba, Argentina.

Correo electrónico: zpalladino@hotmail.com 